\author{
Barbara MARKIEWICZ ${ }^{1}$ \\ Leonard ZIEMIAŃSKI ${ }^{2}$
}

\title{
NUMERICAL MODAL ANALYSIS OF THE FRP COMPOSITE BEAM
}

\begin{abstract}
The paper presents models of the beam made of a fibre-reinforced polymer (FRP) composite, which will act as a girder in simply supported footbridges. The behaviour of the composite beam can be described by various models with good results. The aim is to investigate which parameters, describing the model, significantly affect the results in the modal analysis. This research is focused on creating the most accurate numerical beam model. The material is assumed to have the averaged material constants of individual components. In the first approach the beam is treated as a prismatic beam with a continuous distribution of mass, for which the natural frequency is calculated using the closed-form solutions. Euler-Bernoulli beam theory is applied and followed by Timoshenko theory, which takes into account the influence of shear deformation and rotational inertia effects. Using FEM analysis software ADINA in following steps are included: overhangs, stiffening by ribs, load caused by concrete fillings in supports area and the cross-sectional warping phenomenon. The results for all the numerical models are presented as eigen-frequencies and corresponding mode shapes. Then they are compared with results obtained for the shell FEM model. The author's aim is to find a simple model of the beam, which could successfully replace the complicated shell or solid FEM model, which are not applicable for practical design.
\end{abstract}

Keywords: modal analysis, FEM modelling, FRP composite beam

\section{Introduction}

Nowadays it is difficult to imagine any structure calculations without using a computer program. The efficiency of a software allows to achieve a very accurate representation of the real structure by a numerical model. However, the more sophisticated model is, the more difficult is to recognize and locate potential errors. Therefore, one should consider only those system's properties

\footnotetext{
Author for correspondence: Barbara Markiewicz, Rzeszow University of Technology, Poznanska Street 2, 35-959 Rzeszow, +48 17865 1619, bmarkiewicz@prz.edu.pl

2 Leonard Ziemiański, Rzeszow University of Technology, Poznanska Street 2, 35-959 Rzeszow, +48 17865 1353, ziele@prz.edu.pl
} 
and phenomena, that are essential for conducted analysis and exclude these, which have no significant effect on the final results.

That way, the numerical model can be easily modified and adjusted to real, physical model.

\section{Description of the studied structure}

\subsection{Footbridges made of composites}

The presented in Fig. 1 beam is a tested fragment of a girder in simply supported footbridges. The beam is made of a fibre-reinforced polymer (FRP).

There are many reasons for the increased use of composite materials in bridge engineering, like high strength or low weight. However, one of the major problems of bridge structures, including footbridges, is their durability. The problem of durability is mainly related to corrosion of steel and reinforced concrete structures, FRP elements do not corrode.

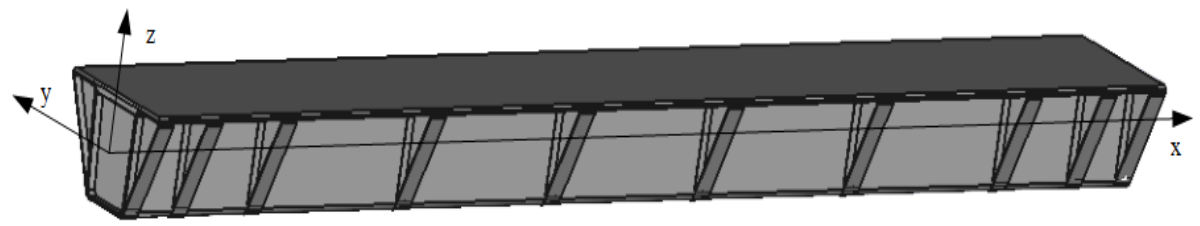

Fig. 1. The tested beam

Rys. 1. Badana belka

\subsection{Description of the tested beam}

The tested beam with a length of $13.5 \mathrm{~m}$ and span equal $12 \mathrm{~m}$ consists of two basic elements: a box girder and deck [1].

The top and bottom flanges consist of alternating laminates of glass and carbon FRP, and act as main load-bearing elements in the cross-section. Box beam webs are composites of two outer layers of glass FRP and filling of $15 \mathrm{~mm}$ of foam. Rounded corners of variable thickness are made of a glass mat and they are segments of transition between the webs and the flanges [1].

The box girder is stiffened by diaphragms and external ribs (Fig. 2). The webs of the ribs are formed similar as a box girder webs, but their flanges are laminates of glass. It is assumed that all components are connected by an epoxy adhesive [1].

The material constants of the basic layers are shown in Table.1. 


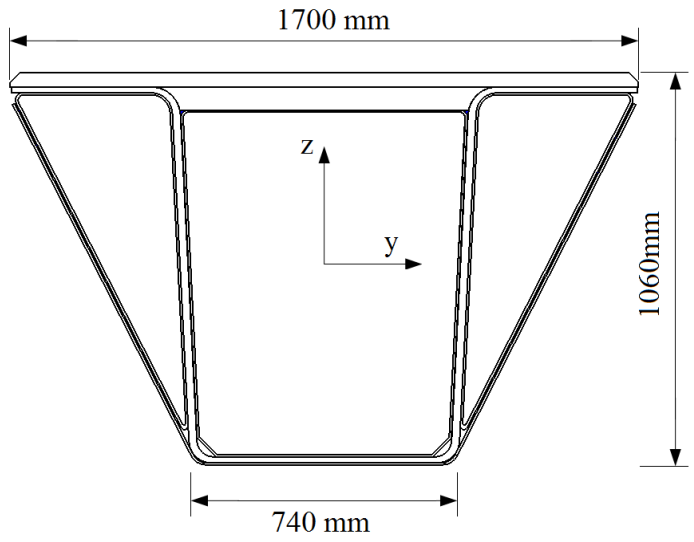

Fig. 2. Elements and dimensions of cross-section of the beam according to [1]

Rys. 2. Elementy i wymiary przekroju poprzecznego belki na podstawie [1]

Because of the different solutions of the support zones, the beam is not perfectly symmetrical. One of the support areas is designed to be filled with the $\mathrm{C} 25 / 30$ concrete and reinforced with composite rods and steel T-profiles. In the other support area are applied two additional internal diaphragms. The space between them is filled with the closed section profiles and the C25/30 concrete, but only to a height of $0.45 \mathrm{~m}$ measured from the bottom flange of the girder [1].

Table 1. The parameters of the composite load-bearing layers according to [1]

Tabela 1. Parametry nośnych warstw kompozytowych na podstawie [1]

\begin{tabular}{|l|c|c|c|c|c|}
\hline \multirow{3}{*}{ Material } & \multicolumn{2}{|c|}{ Young's modulus } & $\begin{array}{c}\text { Poisson's } \\
\text { ratio }\end{array}$ & $\begin{array}{c}\text { Shear mo- } \\
\text { dulus }\end{array}$ & $\begin{array}{c}\text { Specific } \\
\text { weight }\end{array}$ \\
\cline { 2 - 6 } & $\mathrm{E}_{\mathrm{x}}$ & $\mathrm{E}_{\mathrm{y}}$ & $v_{\mathrm{xy}}$ & $\mathrm{G}_{\mathrm{xy}}$ & $\rho$ \\
\cline { 2 - 6 } & {$[\mathrm{GPa}]$} & {$[\mathrm{GPa}]$} & {$[-]$} & {$[\mathrm{GPa}]$} & {$\left[\mathrm{kN} / \mathrm{m}^{3}\right]$} \\
\hline Glass FRP & 24,0 & 24,0 & 0,14 & 4,37 & 21,5 \\
\hline $\begin{array}{l}\text { Carbon } \\
\text { FRP }\end{array}$ & 125,0 & 8,0 & 0,31 & 4,00 & 15,7 \\
\hline
\end{tabular}

\section{Modelling assumptions}

\subsection{Scheme of the modelling process}

The aim is to create a set of models of a beam and investigate, which parameters describing the model significantly affect the results in the modal analysis. The next step is to analyze these results and find a simple 1-D model that can successfully replace the complicated shell FEM model. 
Calculations have been performed for two variants of the material, visible on the diagram in Fig.3. Also, characteristics of the cross-section have been shown in two ways: as for homogeneous material and as for the cross section made of two different materials, so-called weighted characteristics.

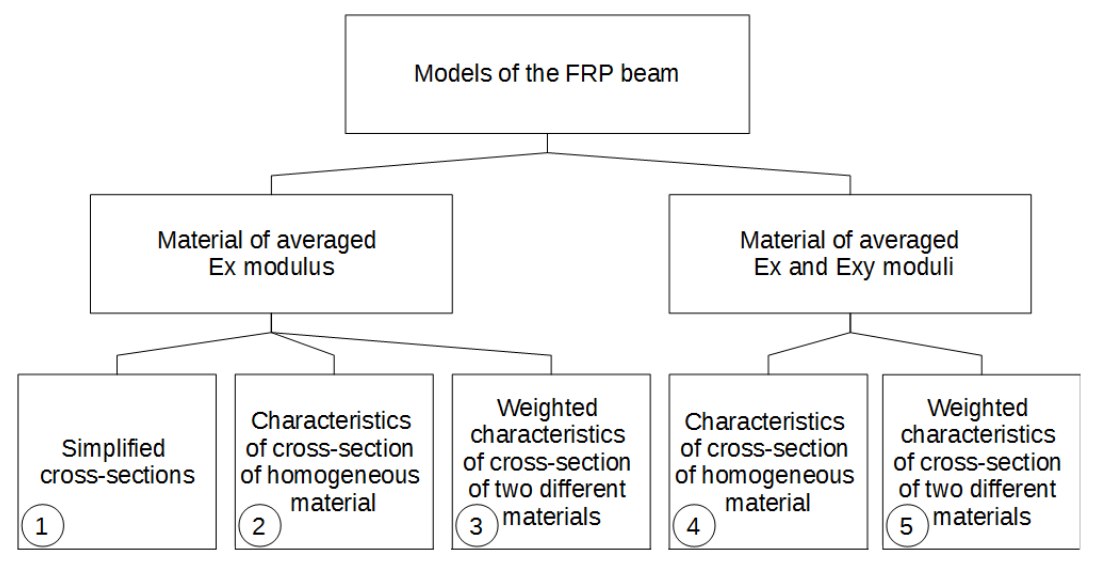

Fig. 3. Scheme of modelling process

Rys. 3. Schemat procesu modelowania

\subsection{Material constants}

As one of the assumptions has been adopted an isotropic material with averaged constants. In determining the material characteristics the foam has not been taken into consideration, because it acts only as a distance between the load-bearing layers.

Two parallel approaches have been considered. In the first case has been adopted an averaged module based on moduli Ex of the layers, while the second variant has been the average of moduli: Ex and Ey (called Exy).

The material constants have been averaged basing on the percentage of material in cross-sectional area. It has been calculated that layers of glass FRP accounted for $67 \%$ of the unstiffened cross-section, therefore for unstiffened segments of the beam, basing on information in Table 1., Young's modulus has been $\mathrm{Ex}=57.3 \mathrm{GPa}$ and for the second variant on the basis of average values of the moduli Ex and Ey: Exy =38 GPa. In the segments stiffened with diaphragms and ribs the glass FRP account for the $83 \%$. To these areas have been assigned material constants $\mathrm{Ex}=41.2 \mathrm{GPa}$ and $\mathrm{Exy}=31,2 \mathrm{GPa}$.

The material is simplified and treated as isotropic, so the shear modulus has been dependent on the Young's modulus and Poisson's ratio.

Based on the material data, the calculated weight of the beam with the foam has been equal to $118 \mathrm{~kg} / \mathrm{m}$, and for segments with additional stiffening elements: $290 \mathrm{~kg} / \mathrm{m}$. 


\subsection{Characteristics of the cross-section}

In addition to the complicated calculations of characteristics of the actual beam cross-section, in the paper have been presented examples of models with simplified cross-sections. The first model is the box section, in which the outer flanges have been omitted and distance of the walls has been averaged to form of a rectangular tube (Fig. 4 a). The second cross-section has included entire length of the plate, but omits an inclination of the walls (Fig. 4 b).

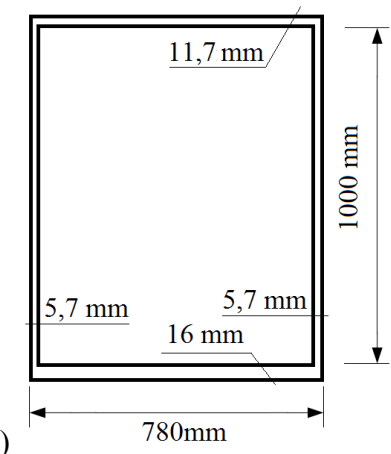

a)

Fig. 4. Simplified cross-sections: a) box, b) c-profile closed with a plate

Rys. 4. Uproszczony przekrój poprzeczny: a) skrzynkowy, b) przekrój zamknięty z płytą

The characteristics for the actual cross-section have been also somewhat simplified and calculated as for a homogeneous material [2]. The foam has been completely omitted. The results have been presented below:

$$
A=0,056 \mathrm{~m}^{2}, \quad I_{y}=104,1 \cdot 10^{-4} \mathrm{~m}^{4}, \quad I_{z}=123,1 \cdot 10^{-4} \mathrm{~m}^{4} .
$$

and for the stiffened segments:

$$
A=0,114 \mathrm{~m}^{2}, \quad I_{y}=181,8 \cdot 10^{-4} \mathrm{~m}^{4}, \quad I_{z}=264,1 \cdot 10^{-4} \mathrm{~m}^{4} .
$$

As the second variant of the calculation have been created weighted characteristics of a cross section of two materials described by Ex modulus. The basic modulus in calculations has been $\mathrm{Ex}=24$ GPa for glass FRP material.

$$
A^{\prime}=0,116 \mathrm{~m}^{2}, \quad I_{y}{ }^{\prime}=260 \cdot 10^{-4} \mathrm{~m}^{4}, I_{z}{ }^{\prime}=279 \cdot 10^{-4} \mathrm{~m}^{4} .
$$

and for the stiffened segments:

$$
A^{\prime}=0,173 m^{2} \quad I_{y}^{\prime}=300 \cdot 10^{-4} \mathrm{~m}^{4}, \quad I_{z}^{\prime}=426 \cdot 10^{-4} \mathrm{~m}^{4} .
$$


The weighted characteristics for variant of using the averaged Exy modules have been presented below. In this case the basic module has been also for glass FRP material and Exy $=24 \mathrm{GPa}$.

$$
A_{s}{ }^{\prime}=0,081 \mathrm{~m}^{2}, \quad I_{y s}{ }^{\prime}=171 \cdot 10^{-4} \mathrm{~m}^{4}, \quad I_{z s}{ }^{\prime}=187 \cdot 10^{-4} \mathrm{~m}^{4} .
$$

and for the stiffened segments:

$$
A_{s}{ }^{\prime}=0,138 m^{2}, \quad I_{y s}{ }^{\prime}=214 \cdot 10^{-4} m^{4}, \quad I_{z s}{ }^{\prime}=334 \cdot 10^{-4} m^{4} .
$$

\section{Assumed models of FRP beam}

In preliminary calculations beam has been treated as a prismatic bar with continuous mass distribution. The frequencies have been calculated directly from closed-form expressions for a simply supported beam with a span of $12 \mathrm{~m}$. At first the Euler's approach has been used and then the Timoshenko's approach, taking into account the influence of shear strain and rotational inertia.

Natural frequency of transverse vibrations [3]:

$$
\omega_{n}=\left(n \frac{\pi}{L}\right)^{2} \sqrt{\frac{E J}{\mu}}
$$

where: $\quad J-$ area moment of inertia of the cross-section $\left[\mathrm{m}^{4}\right]$,

$\mathrm{L}-\operatorname{span}[\mathrm{m}]$,

$\mu$ - beam mass per unit length $[\mathrm{kg} / \mathrm{m}]$,

$\mathrm{n}$ - number of mode [-].

Natural frequency of longitudinal vibrations [3]:

$\omega_{n}=\frac{2 n-1}{2} \cdot \frac{\pi}{L} \sqrt{\frac{E A}{\mu}}$

where: $\quad \mathrm{A}-$ area of the cross-section $\left[\mathrm{m}^{2}\right]$.

Natural frequency of torsional vibrations [3]:

$\omega_{n}=n \frac{\pi}{L} \sqrt{\frac{G J_{s} A}{J_{o} \mu}}$

where: $\quad \mathrm{J}_{\mathrm{s}}-$ torsion constant of the cross-section $\left[\mathrm{m}^{4}\right]$,

$\mathrm{J}_{\mathrm{o}}$ - polar moment of inertia $\left[\mathrm{m}^{4}\right]$.

The influence of shear deformation and rotational inertia effects [3]: 


$$
\omega_{n}=\frac{\left(n \frac{\pi}{L}\right)^{2} \sqrt{\frac{E J}{\mu}}}{\sqrt{1+\left(n \frac{\pi}{L} \sqrt{\frac{J}{A}}\right)^{2}\left(1+\frac{E}{k G}\right)}}
$$

where: $\quad k-$ the Timoshenko shear coefficient.

In the following steps, using the ADINA program, have been included: overhangs, stiffening by diaphragms and ribs (Fig. 5) and a mass of concrete filling the areas of support. Due to the closed cross-section of the beam, high density of stiffeners and concrete filling of zones of the support, the warping phenomenon has been excluded.

The masses over the supports have been calculated as $2850 \mathrm{~kg}$ over the left one and $730 \mathrm{~kg}$ over the right. The calculations have been performed for two cases: with the rotation around the $\mathrm{x}$-axis blocked in only one or in both supports.

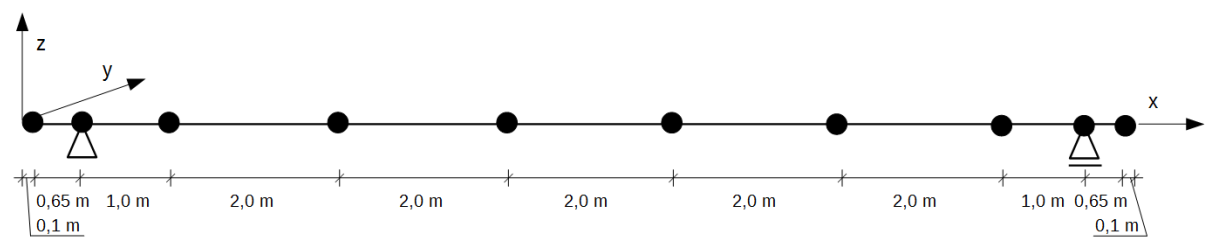

Fig. 5. Diagram with included overhangs and stiffening (black dots) of the beam

Rys. 5. Wykres pokazujący wsporniki i usztywnienia (czarne kropki) w belce

For model with included additional masses of concrete the scheme of the supporting has been no longer symmetrical. The mass over left support is bigger, so the case with the rotation around the x-axis blocked in the left support differ from the one with blocked x-rotation in the right support. In the tables, these cases have been separated by a slash like in the pattern: blocked $\mathrm{x}-$ rotation in the left / right support.

The results for all the models have been presented as frequencies.

\section{Results of the analysis}

Results for all the assumed 1-D models of the beam
Type of the element:
A - the Euler-Bernoulli beam,
$\mathrm{B}$ - the Timoshenko beam.
Boundary conditions: $\quad 1$-the $\mathrm{x}$-rotation blocked in one of the supports,
2 - the x-rotation blocked in both supports. 
In Table 2 and Table 3 have been presented the results for the simplified crosssections: box and U-section with the plate. Two variants of support have been considered. The simple supported beam made of material with $\mathrm{Ex}=57.3 \mathrm{GPa}$ has been considered $\left(1^{\text {st }}\right.$ model in scheme in Fig. 3$)$.

Table 2. Results for box cross-section and Ex material (No. 1 in Fig.3)

Tabela 2. Wyniki dla przekroju poprzecznego skrzynkowego i materiału Ex (Nr 1 na Rys. 3)

\begin{tabular}{|c|c|c|c|}
\hline \multirow{2}{*}{\multicolumn{2}{|c|}{$\begin{array}{l}\text { Eigen-frequencies [Hz] } \\
\text { and corresponding } \\
\text { mode shapes }\end{array}$}} & \multicolumn{2}{|c|}{ Simply supported beam } \\
\hline & & A & $\mathrm{B}$ \\
\hline \multicolumn{2}{|c|}{1 bending $x y$} & 12,8 & 12,5 \\
\hline \multicolumn{2}{|c|}{1 bending $x z$} & 19,2 & 18,7 \\
\hline \multicolumn{2}{|c|}{2 bending $x y$} & 51,4 & 47,2 \\
\hline \multicolumn{2}{|c|}{2 bending $x z$} & 77,0 & 68,9 \\
\hline \multirow{2}{*}{ torsiona } & 1 & & \\
\hline & 2 & & \\
\hline \multicolumn{2}{|c|}{ longitudinal } & & \\
\hline \multicolumn{2}{|c|}{3 bending $x y$} & 115,6 & 97,2 \\
\hline
\end{tabular}

Comparing the first frequencies of these two cases it can be seen that the inclusion of the full length of the flanges stiffens the beam on the xy direction and decreases the torsional frequencies.

In case of boundary conditions the differences are only between frequencies for torsional vibrations. The frequencies are reduced for blocked x-rotation in one of the beam ends.

Table 3. Results for 'u-section+plate' cross-section and Ex material (No. 1)

Tabela 3. Wyniki dla przekroju poprzecznego U + płyta i materiału Ex (Nr 1) $\square$

\begin{tabular}{|l|c|c|}
\hline \multirow{2}{*}{$\begin{array}{c}\text { Eigen-frequencies [Hz] } \\
\text { and corresponding } \\
\text { mode shapes }\end{array}$} & A & B \\
\cline { 2 - 3 } 1 bending $x z$ & 20,4 & 19,3 \\
\hline 1 bending xy & 22,7 & 21,8 \\
\hline 2 bending xz & 81,5 & 67,7 \\
\hline 2 bending xy & 90,9 & 78,9 \\
\hline \multirow{2}{*}{ torsional 1} & \multicolumn{2}{|c|}{78.1} \\
\cline { 2 - 4 } & 2 & 18,2 \\
\hline longitudinal & \multicolumn{2}{|c|}{96,0} \\
\hline 3 bending xz & \multicolumn{2}{|c|}{129,4} \\
\hline
\end{tabular}

Next models has been created using the calculated geometric characteristics for defining the cross-section. 
In Table 4 have been shown the results for a material with an averaged modulus $\mathrm{Ex}=57.3 \mathrm{GPa}\left(2^{\text {nd }}\right.$ model in Fig.3), as in the previous simplified cases. In relation to the U-section with plate cross-section, theoretically the only difference has been the inclination of the webs, in practice a more accurate determination of all the geometric characteristics.

The moment of inertia with respect to z-axis has been increased relative to the moment of inertia with respect to y-axis, it has resulted in a re-order of occurring mode shapes. The first frequency in this case has referred to the bending in xz-plane vibrations. For B option - the Timoshenko beam, all of the frequencies for bending vibrations have been smaller than those for the beam of Euler-Bernoulli theory. However, it does not matter in the case of results for torsional as well as longitudinal vibrations.

Table 4. Results for cross-section made of homogeneous Ex material (No. 2)

Tabela 4. Wyniki dla przekroju poprzecznego wykonanego z homogenicznego materiału Ex (Nr 2) $\square$

\begin{tabular}{|c|c|c|c|c|c|c|c|c|c|}
\hline \multirow{2}{*}{\multicolumn{2}{|c|}{$\begin{array}{c}\text { Eigen-frequencies } \\
{[\mathrm{Hz}]} \\
\text { and corresponding } \\
\text { mode shapes } \\
\end{array}$}} & \multicolumn{2}{|c|}{ Simple model } & \multicolumn{2}{|c|}{ Overhangs } & \multicolumn{2}{|c|}{ Stiffening } & \multicolumn{2}{|c|}{ Concrete filling } \\
\hline & & A & B & A & B & A & B & A & B \\
\hline \multicolumn{2}{|c|}{1 bending $\mathrm{XZ}$} & 24,4 & 22,5 & 24,3 & 22,4 & 22,9 & 21,2 & 21,3 & 20,1 \\
\hline \multicolumn{2}{|c|}{1 bending $x y$} & 26,5 & 25,9 & 26,4 & 25,8 & 25,0 & 24,5 & 23,0 & 22,5 \\
\hline \multirow{2}{*}{1 torsional } & 1 & \multicolumn{2}{|c|}{35,7} & \multicolumn{2}{|c|}{33,6} & \multicolumn{2}{|c|}{32,5} & \multicolumn{2}{|c|}{$25,9 / 12,8$} \\
\hline & 2 & \multicolumn{2}{|c|}{71,5} & \multicolumn{2}{|c|}{71,5} & \multicolumn{2}{|c|}{71,9} & \multicolumn{2}{|c|}{77,7} \\
\hline \multirow{2}{*}{2 torsional } & 1 & \multicolumn{2}{|c|}{107,4} & \multicolumn{2}{|c|}{102,6} & \multicolumn{2}{|c|}{98,2} & \multicolumn{2}{|c|}{$89,12 / 79,9$} \\
\hline & 2 & \multicolumn{2}{|c|}{143,2} & \multicolumn{2}{|c|}{143,2} & \multicolumn{2}{|c|}{143,8} & \multicolumn{2}{|c|}{148,7} \\
\hline \multicolumn{2}{|c|}{2 bending $x z$} & 95,7 & 73,06 & 94,5 & 72,7 & 88,7 & 69,7 & 70,0 & 57,8 \\
\hline \multicolumn{2}{|c|}{ longitudinal } & \multicolumn{2}{|c|}{108,6} & \multicolumn{2}{|c|}{102,3} & \multicolumn{2}{|c|}{94,3} & \multicolumn{2}{|c|}{72,2} \\
\hline
\end{tabular}

In Table 4 have been listed more information about the beam. As her overhangs, which have slightly $(0.01 \mathrm{~Hz})$ reduced results for the first frequency. Stiffeners have been included as a change of stiffness and geometric characteristics of cross-sections on the segments corresponding to the occurrence of diaphragm and ribs. Their weights have been added. The results for this model have been smaller. At the ends of the beam have been added the masses of the concrete fillings, what has caused further reduction the frequency of vibration from the initial $24.4 \mathrm{~Hz}$ to $20.1 \mathrm{~Hz}$. Because the masses of concrete on supports have been different, the beam has gained yet another variant of support for a possible $\mathrm{x}$-rotation from the left or right. When the $\mathrm{x}$-rotation on the support with concrete of bigger mass has been free, obtained frequencies have been lower. In this case the first frequency of $12.8 \mathrm{~Hz}$ has referred to torsional vibration. It can be concluded that the free rotation in case of the heavier weight of the concrete caused the extension of the period of the torsional vibration. 
A similar table has been created for material with modulus Exy $=38 \mathrm{GPa}$ $\left(3^{\text {rd }}\right.$ model in Fig.3). The package of similar dependency results as in previous case has been obtained and presented in Table 5 . These results have respectively depended on a lower Young's modulus. The lowest frequency have been obtained as before, for torsional vibration frequency of last type of model, and has been equal $10.4 \mathrm{~Hz}$, so $2.4 \mathrm{~Hz}$ less than previously.

Table 5. Results for cross-section made of homogeneous Exy material (No. 4) $\square$ Tabela 5. Wyniki dla przekroju poprzecznego wykonanego z homogenicznego materiału Exy (Nr 4)

\begin{tabular}{|c|c|c|c|c|c|c|c|c|c|}
\hline \multirow{2}{*}{\multicolumn{2}{|c|}{$\begin{array}{c}\text { Eigen-frequencies } \\
{[\mathrm{Hz}]} \\
\text { and corresponding } \\
\text { mode shapes }\end{array}$}} & \multicolumn{2}{|c|}{ Simple model } & \multicolumn{2}{|c|}{ Overhangs } & \multicolumn{2}{|c|}{ Stiffening } & \multicolumn{2}{|c|}{ Concrete filling } \\
\hline & & A & B & A & B & $\mathrm{A}$ & $\mathrm{B}$ & A & B \\
\hline \multicolumn{2}{|c|}{1 bending $\mathrm{xz}$} & 19,9 & 18,3 & 19,8 & 18,3 & 18,7 & 17,4 & 17,4 & 16,5 \\
\hline \multicolumn{2}{|c|}{1 bending $x y$} & 21,6 & 21,1 & 21,5 & 21,0 & 20,5 & 20,0 & 18,8 & 18,4 \\
\hline \multirow{2}{*}{1 torsional } & 1 & \multicolumn{2}{|c|}{29,1} & \multicolumn{2}{|c|}{27,4} & \multicolumn{2}{|c|}{26,5} & \multicolumn{2}{|c|}{$21,0 / 10,4$} \\
\hline & 2 & \multicolumn{2}{|c|}{58,2} & \multicolumn{2}{|c|}{58,2} & \multicolumn{2}{|c|}{58,5} & \multicolumn{2}{|c|}{63,3} \\
\hline \multirow{2}{*}{2 torsional } & 1 & \multicolumn{2}{|c|}{87,4} & \multicolumn{2}{|c|}{82,2} & \multicolumn{2}{|c|}{79,8} & \multicolumn{2}{|c|}{$72,6 / 65,1$} \\
\hline & 2 & \multicolumn{2}{|c|}{116,5} & \multicolumn{2}{|c|}{116,6} & \multicolumn{2}{|c|}{117,2} & \multicolumn{2}{|c|}{126,4} \\
\hline \multicolumn{2}{|c|}{2 bending $\mathrm{xz}$} & 77,9 & 59,5 & 77,0 & 59,2 & 72,6 & 57,0 & 57,1 & 47,3 \\
\hline \multicolumn{2}{|c|}{ longitudinal } & \multicolumn{2}{|c|}{88,5} & \multicolumn{2}{|c|}{83,3} & \multicolumn{2}{|c|}{77,2} & \multicolumn{2}{|c|}{59,1} \\
\hline
\end{tabular}

In Table 6 and Table 7 have been presented the results in similar relations using weighted characteristics of the cross-section. In both cases the basic module used in calculations has been $24 \mathrm{GPa}$ for glass FRP material.

Table 6. Results for the weighted characteristics of cross-section and Ex material (No. 3) $\square$ Tabela 6. Wyniki dla ważonej charakterystyki przekroju poprzecznego i materiału Ex (Nr 3) $\square$

\begin{tabular}{|c|c|c|c|c|c|c|c|c|c|}
\hline \multirow{2}{*}{\multicolumn{2}{|c|}{$\begin{array}{c}\text { Eigen-frequencies } \\
{[\mathrm{Hz}]} \\
\text { and corresponding } \\
\text { mode shapes }\end{array}$}} & \multicolumn{2}{|c|}{ Simple model } & \multicolumn{2}{|c|}{ Overhangs } & \multicolumn{2}{|c|}{ Stiffening } & \multicolumn{2}{|c|}{ Concrete filling } \\
\hline & & A & B & A & B & A & B & A & B \\
\hline 1 bendir & $\operatorname{ng} x z$ & 17,3 & 14,4 & 17,2 & 14,4 & 16,7 & 14,1 & 15,8 & 13,8 \\
\hline 1 bendir & ng xy & 17,9 & 17,5 & 17,9 & 17,5 & 17,45 & 17,1 & 16,3 & 16,0 \\
\hline \multirow{2}{*}{$\begin{array}{l}1 \text { torsio- } \\
\text { nal }\end{array}$} & 1 & \multicolumn{2}{|c|}{12,3} & \multicolumn{2}{|c|}{11,6} & \multicolumn{2}{|c|}{11,5} & \multicolumn{2}{|c|}{$10,7 / 5,3$} \\
\hline & 2 & \multicolumn{2}{|c|}{24,6} & \multicolumn{2}{|c|}{24,7} & \multicolumn{2}{|c|}{25,0} & \multicolumn{2}{|c|}{26,2} \\
\hline \multirow{2}{*}{$\begin{array}{l}2 \text { torsio- } \\
\text { nal }\end{array}$} & 1 & \multicolumn{2}{|c|}{37,0} & \multicolumn{2}{|c|}{34,8} & \multicolumn{2}{|c|}{34,7} & \multicolumn{2}{|c|}{$33,0 / 27,8$} \\
\hline & 2 & \multicolumn{2}{|c|}{49,3} & \multicolumn{2}{|c|}{49,3} & \multicolumn{2}{|c|}{50,1} & \multicolumn{2}{|c|}{50,9} \\
\hline \multicolumn{2}{|c|}{2 bending $x z$} & 67,7 & 40,5 & & 40,4 & 64,6 & 40,4 & 52,8 & 36,8 \\
\hline longituc & linal & \multicolumn{2}{|c|}{70,3} & \multicolumn{2}{|c|}{66,2} & \multicolumn{2}{|c|}{63,7} & \multicolumn{2}{|c|}{57,4} \\
\hline
\end{tabular}


For a material with a modulus considering only Ex (Table 4 and Table 6) have been obtained lower frequencies in case of model with weighted characteristics. However, this ratio is different for the case without and with stiffeners, where proportions of the percentage of particular materials in the total area have been changed. In the case of stiffened cross-section these proportion are smaller, because stiffeners have been made of glass FRP of smaller modulus $\mathrm{Ex}=\mathrm{Ey}=24 \mathrm{GPa}$, so their percentage is higher.

Also in case of material of the averaged Exy (Table 5 and Table 7) have been obtained lower frequencies for model with weighted characteristics.

However, weight for characteristics of the carbon FRP material has been smaller, because the ratio of the glass FRP module 24GPa to the averaged carbon FRP module 66.5 GPa has been smaller (comparing to $125 \mathrm{GPa}$ in previous model).

The results in the entire table are lower than those in Table 5.

The final results taking into account the weight of the concrete in Table 6 and Table 7 are comparable.

Table 7. Results for the weighted characteristics of cross-section and Exy material (No. 5) Tabela 7. Wyniki dla ważonej charakterystyki przekroju poprzecznego i materiału Exy (Nr 5) $\square$

\begin{tabular}{|c|c|c|c|c|c|c|c|c|c|}
\hline \multirow{2}{*}{\multicolumn{2}{|c|}{\begin{tabular}{|c|} 
Eigen-frequencies \\
{$[\mathrm{Hz}]$} \\
and corresponding \\
mode shapes
\end{tabular}}} & \multicolumn{2}{|c|}{ Simple model } & \multicolumn{2}{|c|}{ Overhangs } & \multicolumn{2}{|c|}{ Stiffening } & \multicolumn{2}{|c|}{ Concrete filling } \\
\hline & & A & B & A & B & A & B & A & B \\
\hline \multicolumn{2}{|c|}{1 bending $\mathrm{Xz}$} & 16,8 & 16,3 & 16,7 & 16,2 & 16,1 & 14,3 & 15,1 & 13,8 \\
\hline \multicolumn{2}{|c|}{1 bending $x y$} & 17,6 & 17,0 & 17,5 & 16,9 & 17,0 & 16,6 & 15,8 & 15,5 \\
\hline \multirow{2}{*}{$\begin{array}{l}1 \text { torsio- } \\
\text { nal }\end{array}$} & 1 & \multicolumn{2}{|c|}{15,1} & \multicolumn{2}{|c|}{14,2} & \multicolumn{2}{|c|}{14,0} & \multicolumn{2}{|c|}{$12,8 / 6,12$} \\
\hline & 2 & \multicolumn{2}{|c|}{30,2} & \multicolumn{2}{|c|}{30,2} & \multicolumn{2}{|c|}{30,4} & \multicolumn{2}{|c|}{41,3} \\
\hline \multirow{2}{*}{$\begin{array}{l}2 \text { torsio- } \\
\text { nal }\end{array}$} & 1 & \multicolumn{2}{|c|}{45,4} & \multicolumn{2}{|c|}{42,7} & \multicolumn{2}{|c|}{41,9} & \multicolumn{2}{|c|}{$39,6 / 33,6$} \\
\hline & 2 & \multicolumn{2}{|c|}{60,5} & \multicolumn{2}{|c|}{60,5} & \multicolumn{2}{|c|}{60,8} & \multicolumn{2}{|c|}{82,0} \\
\hline \multicolumn{2}{|c|}{2 bending $x z$} & 65,8 & 58,1 & 64,9 & 57,7 & 62,2 & 43,8 & 56,1 & 38,6 \\
\hline \multicolumn{2}{|c|}{ longitudinal } & \multicolumn{2}{|c|}{70,32} & \multicolumn{2}{|c|}{66,2} & \multicolumn{2}{|c|}{63,0} & \multicolumn{2}{|c|}{56,3} \\
\hline
\end{tabular}

Comparison of obtained eigen-frequencies with the results for shell model [1]

Table 8. Eigen-frequencies and mode shapes for the shell model according to [1]

Tabela 8. Częstości drgań własnych i postacie drgań dla modelu powłokowego według [1]

\begin{tabular}{|l|l|l|l|}
\hline Mode shapes & Frequencies $[\mathrm{Hz}]$ & $\begin{array}{l}\text { Frequencies from } \\
\text { Table 5 }[\mathrm{Hz}]\end{array}$ & Difference [\%] \\
\hline 1 bending xz & 16,3 & 16,5 & 1,2 \\
\hline 1 bending xy & 17,8 & 18,4 & 3,4 \\
\hline 1 torsional & 26,8 & 21,0 & 22 \\
\hline 2 torsional & 30,2 & 72,6 & 140 \\
\hline 2 bending xz & 36,5 & 47,3 & 29,5 \\
\hline
\end{tabular}


Some analogy can be found by comparing results obtained for different 1-D models of the beam with the shell model. The closest frequencies to the values shown in Table 8 are those obtained in Table 5 for included stiffeners, the weight of the concrete on the supports and blocked the rotation around the x-axis on the left support. Comparison of the results have been presented below.

The first two frequencies are similar, in the following there are visible differences.

\section{Conclusions}

In the paper has been described a set of simple dynamic models of the beam. Parameters that may affect the frequency have been considered. Thus database has been created, which consisted of obtained frequencies.

The results have been analyzed to find these the most corresponding with frequencies of the shell model presented in [1].

The closest model has proved to be a model No. 3 (Fig. 3). The differences for the first two frequencies are smaller than $4 \%$, but the following frequency values differs by $22 \%$ (Table 8 ).

Some limitations can be seen, caused by such a formulation of the model. However, undeniable advantages are easier and more convenient analysis. With a simple model it is easy to explore, how it changes depending on the assumptions used. What is more, it is possible to adjust it to the actual beam and, if necessary, to create a basis to build the more complex model.

\section{Bibliography}

[1] Poneta, P., Kulpa, M., Siwowski T., Material and performance research on the FRP composite bridge girder, Academic Journals and Conferences of Lwow Polytechnic National University, 38, pp. 235-242.

[2] Piechnik S.: Strength of materials in Civil Engineering, Warsaw-Cracow 1978 (in Polish).

[3] Lewandowski R. Dynamics of civil engineering structures. Poznan University of Technology Publishing House, Poznan 2006 (in Polish)

\section{NUMERYCZNE ANALIZY MODALNE BELKI Z KOMPOZYTU FRP}

\section{Streszczenie}

Tematem pracy jest budowa modeli dynamicznych belki kompozytowej, pełniącej rolę dźwigara w swobodnie podpartych kładkach dla pieszych.

Celem jest zbadanie, które parametry opisujące model istotnie wpływają na zmianę wyników w przeprowadzanej analizie modalnej oraz znalezienie prostego modelu prętowego, który mógłby zastąpić skomplikowany powłokowy model MES.

Modelowanie rozpoczęto od prostej belki wolnopodpartej traktowanej jako pręt pryzmatyczny z ciągłym rozkładem masy, dla którego częstotliwości obliczono wprost 
ze wzorów zamkniętych. Zastosowano podejście Eulera, a następnie uwzględniono wpływy odkształceń postaciowych i bezwładności obrotowej. W kolejnych krokach posługując się programem ADINA uwzględniano kolejne cechy i koncepcje dotyczące belki.

Wyniki dla poszczególnych modeli zestawiono w postaci częstotliwości i porównano z tymi otrzymanymi dla powłokowego modelu MES.

Słowa kluczowe: analiza modalna, modelowanie MES, belka kompozytowa

Przesłano do redakcji:26.05.2015

Przyjęto do druku:10.01.2016

DOI: $10.7862 / \mathrm{rb} .2015 .195$ 